\title{
ラウリル・セチル・オレイルアルコールおよびノニルフェ ノールの低重合ポリオキシェチレンエーテルの表面張力
}

\author{
渡 辺 昭 一 郎 \\ 北里大学（東京都港区芝白金三光町）
}

\author{
Studies on the Surface Tension of Lower Polyoxyethylene Ethers \\ of Lauryl-, Cetyl-, Oleyl-Alcohol and Nonylphenol \\ Shōichirō Watanabe \\ Kitazato University (Shiba Shirogane-sankō-chō, Minato-ku, Tokyo)
}

\begin{abstract}
Author investigated the surface activities of the polyoxyethylene ethers which have the oxyethylene chains of definite lengths. Mono, di, tri, tetra and penta oxyethylene ethers of lauryl, cetyl, oleyl alcohols and nonylphenol, synthesized in our labolatory, were dissolved or suspended in water and the surface tension of the solutions was measured by using du Noüy's surface tension meter. With the exception of cetyl ethers and mono and di oxyethylene lauryl ethers, the surface tensionconcentration curves of the solutions showed same characteristics as those of ordinary surface active agents. Namely, change in the surface tension is little at higher concentration, while it increases rapidly as the concentration decreases for the range below c.m.c.

Furthermore, it was observed that the surface tension of the solutions of paired ethers containing lauryl-oleyl, oleyl-nonylphenyl, and nonylphenyl-lauryl, having tetraoxyethylene chain respectively, was in a range between those of individuals of the pair ethers. Exploratory experiments were also carried out with other combinations and the effect was studied.
\end{abstract}

\section{1 緒 言}

市販ポリオキシエチレン系非イオン界面活性剈の性 質, 特にその界面活性については従来数多くの報告があ る。その中で高級アルコール招よびノニルフェノールを 原料とするものの表面張力に関しては Baldacci ${ }^{1}$ が $\mathrm{C}_{10}$, $\mathrm{C}_{12}, \mathrm{C}_{14}$ 呿よび $\mathrm{C}_{18}$ のアルコールの 2.9 ないし 35.8 モ ルエチレンオキシド付加エーテルの水溶液について, ま

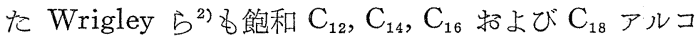
一ルから成るもののポリオキシエチレンエーテルの水溶 液についてその表面張力を測定している。また Lange ${ }^{3)}$ は $\mathrm{C}_{6}$ ないし $\mathrm{C}_{18}$ のアルコールのエチレンオキシド 4 ないし $10 \mathrm{~mol}$ 付加エーテルの表面張力を測定した。 Stauff ら ${ }^{4)}$ ほラウリルアルコールのポリオキシエチレン エーテルを用いてとの水溶液の表面張力が約 $30 \mathrm{~min}$ 後 飞一定值を示すことを見出し，中川らら占同様な結果に ついて報告している。さらに, そセル形成臨界濃度 (CMC) と表面張力の関係飞ついては Cohen ${ }^{6}$, Hsiao $5^{7)}$, Becher $^{8)}$, 中川 $5^{5)}$, 石井ら ${ }^{9)}$ そのほかの報告があ る。たと党ば中川らは流下式分子蒸留装置により混合エ 一テルを分留し，その留分につき混合したものと，混合 しないるのとの表面張力を測定して，混合しないるのの 方が $\mathrm{CMC}$ を示す表面張力ー濃度曲線の折れが鋭くなる
ことを見出し，石井らは 6 種のオクチルフェノール異性 体の表面張力を測定し, $o$ - 呿よび $p$ - 異性体, 直鎖招 よび分鎖異性体間の表面張力低下能の違いとついて報告 している。また Meyhew ら ${ }^{10)}$ が混合エーテルの性質が その成分の分布状態により影響を受けることを報告して いるが，単一エーテルと，平均分子量がそれと同じ混合 エーテルの表面張力低下能は異なるるのと考克られる。

一方エチレンオキシドの付加モル数の少ない単一ポり オキシエチレンアルキルエーテルの合成に関しては比較 的数多くの研究が行なわれているが，これら単一エーテ ルの界面活性についてはほとえで知られていない。篠田

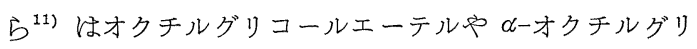
セリルエーテルなどの表面張力を測定している。

著者はラウリル，セチル，オレイルアルコール捛よび ノニルフェノールのモノからペンタまでのオキシエチレ ンエーテルの水溶液の表面張力を測定し, その表面張 力ー濃度曲線から水溶性が小さいるのでる, たと光ばオ キシエチレン鎖が 1 個のものでもラウリルとセチルを除 きミセル形成臨界濃度 (CMC) を示すととを認めた。 さらに水にほとんど不溶であるセテルエーテルに, 比較 的水飞溶け, かっ CMC を示すほかのエーテルを混 合した場合，後者を約 $1 / 3$ 加光ると前者が水溶けて CMC を示す表面張力-濃度曲線が得られるととを見出 
表-1 各オキシエチレンエーテルの定数

\begin{tabular}{|c|c|c|c|c|c|}
\hline $\mathrm{R}-\mathrm{O}-\left(\mathrm{C}_{2} \mathrm{H}_{4} \mathrm{O}\right) n \mathrm{H}$ & \multirow{2}{*}{$\frac{\mathrm{bp}\left({ }^{\circ} \mathrm{C} / \mathrm{mmHg}\right)}{129 \sim 133 / 2}$} & \multirow{2}{*}{$\begin{array}{c}n_{D}^{25} \\
1.4460\end{array}$} & $\mathrm{R}-\mathrm{O}-\left(\mathrm{C}_{2} \mathrm{H}_{4} \mathrm{O}\right) n \mathrm{H}$ & \multirow{2}{*}{$\begin{array}{c}\mathrm{bp}\left({ }^{\circ} \mathrm{C} / \mathrm{mmHg}\right) \\
200 / 2.5\end{array}$} & \multirow{2}{*}{$\frac{n_{D}^{25}}{1.4614}$} \\
\hline $\mathrm{R}=\mathrm{C}_{12} \mathrm{H}_{25} \quad n=1$ & & & $\mathrm{R}=\mathrm{C}_{18} \mathrm{H}_{35}$ & & \\
\hline 2 & $165 \sim 170 / 2$ & 1.4488 & 2 & $187 \sim 194 / 1$ & 1.4614 \\
\hline 3 & $190 \sim 193 / 2$ & 1.4521 & 3 & $230 \sim 240 / 3$ & 1.4614 \\
\hline 4 & $180 \sim 185 / 1$ & 1.4543 & 4 & $240 \sim 250 / 1.5$ & 1.4630 \\
\hline 5 & $207 \sim 210 / 0.8$ & 1.4557 & 5 & $114 \sim 135 / 6 \times 10^{-5 *}$ & 1.4640 \\
\hline $\mathrm{R}-\mathrm{O}-\left(\mathrm{C}_{2} \mathrm{H}_{4} \mathrm{O}\right) n \mathrm{H}$ & $\mathrm{mp}$ & & $\mathrm{R}-\mathrm{O}-\left(\mathrm{C}_{2} \mathrm{H}_{4} \mathrm{O}\right) n \mathrm{H}$ & $\mathrm{bp}\left({ }^{\circ} \mathrm{C} / \mathrm{mmHg}\right)$ & $n_{D}^{20}$ \\
\hline $\mathrm{R}=\mathrm{C}_{16} \mathrm{H}_{33} \quad n=1$ & $39.0 \sim 40.0$ & - & $\mathrm{R}=\mathrm{C}_{9} \mathrm{H}_{19} \cdot \mathrm{C}_{6} \mathrm{H}_{4} n=1$ & $150 \sim 160 / 6$ & 1.5135 \\
\hline 2 & $39.5 \sim 41.0$ & - & 2 & $185 \sim 215 / 7$ & 1.5098 \\
\hline 3 & $45.5 \sim 46.0$ & - & 3 & $225 \sim 226 / 4$ & 1.5042 \\
\hline 4 & $33.5 \sim 34.0$ & - & 4 & $215 \sim 236 / 1$ & 1.5000 \\
\hline 5 & $38.8 \sim 40.2$ & - & 5 & $180 \sim 192 / 0.08^{* *}$ & 1.4980 \\
\hline
\end{tabular}

注） * 流下式分子蒸留装置の加熱面の温度

** ポット式分子蒸留装置で蒸留を行なった。温度は蒸発面の温度

した。また二成分混合物水溶液の表面張力を測り各単一 エーテルの表面張力の值の中間にはいることを認めた。

\section{2 実験}

\section{$2 \cdot 1$ 実験材料}

実験に用いたモノからペンタまでのオキシェチレンエ 一テルはすべて著者ら ${ }^{12)}$ が合成したすのでそれらの定 数の一部を表-1 と示す。

\section{$2 \cdot 2$ 実 験}

所定の濃度の各エーテル水溶液を作り，ペトリ皿に入 れ，リングを液面から放して㨟いて $1 \mathrm{hr}$ 放置して表面 層を安定させてから du Noüy の表面張力計で測定を行 ない，結果については Harkins 特よび Jordan の補正 を行なった ${ }^{13), 14}$ 。な扣放置の際は容器にふたをして蒸発 を防いだ。同一試料については上記操作を繰り返し行な った。また混合物水溶液の場合子混合してから $1 \mathrm{hr}$ 放 置して測定を行なった。また一部のラウリルエーテル水 溶液については Ostwald の粘度計 (No. 2) を用いて相 対粘度を測定した。

\section{3 実験結果および考察}

\section{$3 \cdot 1$ 単一エーテルの表面張力}

\section{$3 \cdot 1 \cdot 1$ ラウリルエーテル}

図-1 Vとの結果を示す。界面活性剤水溶液では CMC に相当する濃度を境とし，これ以上の濃度では表面張力 はあまり変わらず，これ以下の濃度になると急に増加す るのが普通である。ラウリルエーテルではエチレンオキ シドの付加モル数が 3〜 $5(n=3 \sim 5)$ のものについては 上記の傾向を示す曲線が得られ，この結果からはえセル 形成が行なわれていると考光られるが $n=1$ と 2 は透明 な溶液が得られるような低濃度でも, 表面張力に関して は一般の界面活性剤のような傾向を示さず，ミセル形成 の現象が見られないと考觉られる。

な招 $n=1,2$ 打よび 4 について粘度を測定したが， Vetter $^{15)}$ 特よび佐多ら ${ }^{16)}$ によれば界面活性剤溶液の相
対粘度は濃度の増加につれて大とな り CMCに和いて屈折が見られる。 しかしこの点は㐫りり明りょうでな Wので佐多 ${ }^{14)}$ は $\left(\eta_{r}-1\right) / C\left(\eta_{r}:\right.$ 相 対粘数, $C$ : 濃度 $\mathrm{mol} /$ l) と $C$ の曲 線永画くと CMC 亿相当する濃度で 極小を示すことを報告している。著 者の場合 $\eta_{r}-C$ 曲線では判明しにく いが $\left(\eta_{r}-1\right) / C-C$ 曲線を画くと $n$ $=1$ と 2 ののは極小が認められな いが $n=4$ の場合, 表面張力の結果 から得られる CMC とかなり一致し た濃度の点で極小が認められた。こ

れらの結果を図-2 に示す。

$3 \cdot 1 \cdot 2$ オレイルエーテル

図-3 そ炎の結果を示す。 $n=1 \sim 5$ の範囲ではすべて

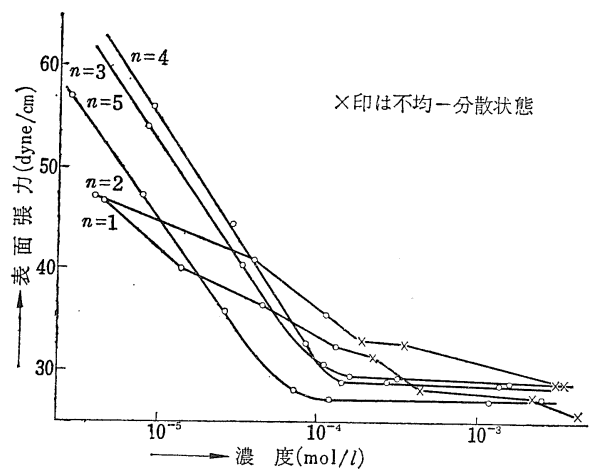

図-1 ラウリルエーテルの表面張力 $\left(25^{\circ} \mathrm{C}\right)$

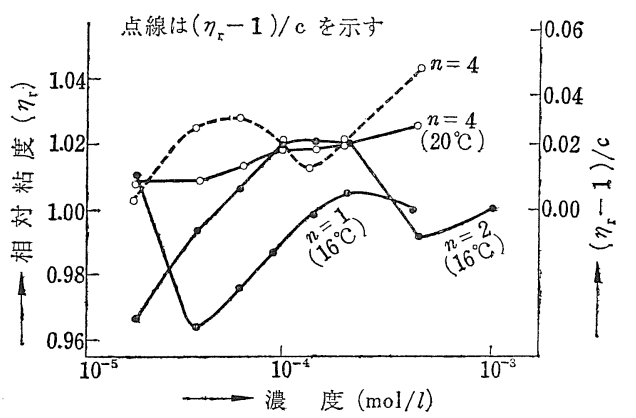

図-2ラウリルエーテル水溶液の粘度

界面活性剤の曲線と同様な傾向を示し， $n$ が増すほど表 面張力の低下も大きい。これは親油基中に二重結合が存 在し溶解性が大きいためと思われる。をた ると， 1 から 5 までの範囲内では CMC に相当する濃 度が少しづつではあるが減少して特り,これは Becher ${ }^{8)}$ の報告と同じ傾向を示している。

$3 \cdot 1 \cdot 3$ ノニルフェニルエーテル

図-4 とその結果を示す。 $n=1 \sim 5$ のいずれもオレイ 


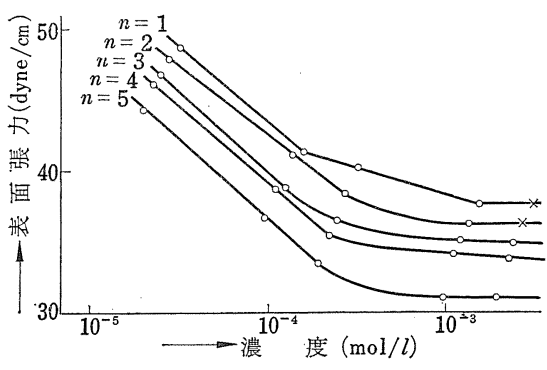

図-3 オレイルエーテルの表面張力 $\left(25^{\circ} \mathrm{C}\right)$ ルエーテルの場合と同様な曲線が得られた。また かが大 きくなるほど表面張力も低下する。ノニルフェニルエー テルの場合は CMCを示す点が明らかに認められ，その 濃度は $n$ が大になるに従い小となっている。

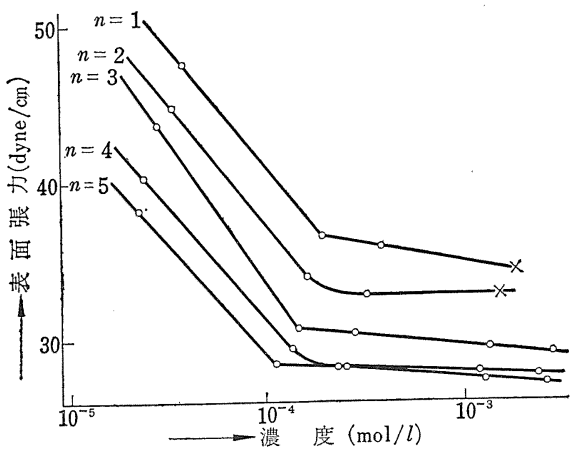

图-4ノニフェニルエーテルの表面張力 $\left(25^{\circ} \mathrm{C}\right)$

$3 \cdot 1 \cdot 4$ セチルエーテル

表-2 そその結果を示すが $n=1 〜 5$ の範囲では水に対 する溶解性がきわめて小さく透明な水溶液が得にくい。 したがって表中の值の多くは参考值飞過ざずこれらの結 果から何の結論も得られないが $n=5$ とついては, 他の エーテルのような曲線にやや近い傾向子認められ， $n$ が 6 あるいはとれ以上の場合初めてミセル形成などの界 面活性が現われるのではないかと考光られる。

表-2 セチルエーテル $\left[\mathrm{C}_{16} \mathrm{H}_{33} \mathrm{O}\left(\mathrm{C}_{2} \mathrm{H}_{4} \mathrm{O}\right) n \mathrm{H}\right]$ の表面張力 $\left(25^{\circ} \mathrm{C}\right)$

\begin{tabular}{l|c|c|c|c|c}
\hline 濃度 $\mathrm{g} / l$ & $n=1$ & $n=2$ & $n=3$ & $n=4$ & $n=5$ \\
\hline 0.05 & $(35.9) *$ & $(38.8)$ & $(28.9)$ & $(43.3)$ & $(29.2)$ \\
0.01 & $(38.3)$ & $(29.1)$ & $(30.3)$ & $(43.3)$ & $(30.1)$ \\
0.005 & $(34.2)$ & $(31.0)$ & $(42.5)$ & $(46.1)$ & $(32.4)$ \\
0.003 & $(36.0)$ & $(31.8)$ & $(41.5)$ & $(50.3)$ & 33.0 \\
0.001 & $(43.6)$ & $(46.4)$ & $(42.4)$ & 51.3 & 34.4 \\
0.0003 & 50.7 & 57.5 & 45.4 & 52.6 & 43.5 \\
0.0001 & 52.7 & 60.6 & 52.1 & 59.4 & 61.6 \\
\hline
\end{tabular}

注）（）内は不均一分散

3・1.5 ラウリルおよびセチルエーテルの非水溶液の 表面張力

以上の実験でラウリルエーテルの一部抽よびセチルエ 一テルはきわめて水に溶けにくいため測定濃度では他の
エーテルとその表面張力を比較することができない。 それゆ劣これらのエーテルのよく溶ける溶㓮としてエタ ノ一ル和よびへキサンを選び，これらに溶解させてその 表面張力を測定した。表-3 とその結果を示す。表面張 力の低下はほとえで認められず，乙たがって試料間拉よ び同一試料の濃度の違いによる差る認められなかった。

表-3 ラウリル和よびセチルエーテルの非水溶液の表面張力 $\left(25^{\circ} \mathrm{C}\right)$

（1）ラウリルエーテルの表面張力（エタノール溶液）

\begin{tabular}{c|c|c|c}
\hline $\mathrm{C}_{12} \mathrm{H}_{25} \mathrm{O}\left(\mathrm{C}_{2} \mathrm{H}_{4} \mathrm{O}\right) n \mathrm{H}$ & $0.1 \mathrm{~g} / l$ & 0.05 & 0.01 \\
\hline$n=1$ & 20.4 & 20.5 & 20.4 \\
2 & 20.9 & 21.0 & 21.0 \\
3 & 20.9 & $21 . \mathrm{I}$ & 21.1 \\
4 & 20.8 & 21.1 & 21.0 \\
\hline
\end{tabular}

（2） セチルエーテルの表面張力（エタノール溶液）

\begin{tabular}{c|c|c}
\hline $\mathrm{C}_{16} \mathrm{H}_{33} \mathrm{O}\left(\mathrm{C}_{2} \mathrm{H}_{4} \mathrm{O}\right) n \mathrm{H}$ & $0.1 \mathrm{~g} / \ell$ & 0.05 \\
\hline$n=1$ & 21.2 & 21.3 \\
2 & 21.3 & 21.3 \\
3 & 21.3 & 21.2 \\
\hline
\end{tabular}

（3）セチルエーテルの表面張力（ヘキサン溶液）

$\left.\begin{array}{r|r}n=1 & 17.4 \\ 5 & 17.5\end{array}\right\} \quad 0.5 \mathrm{~g} / \mathrm{l}$

$3 \cdot 2$ 二成分混合物水溶液の表面張力

\section{$3 \cdot 2 \cdot 1$ 二成分とる CMC 定示場合}

いずれもその表面張力ー濃度曲線が CMC を示すよう なエーテルを混合した場合について実験を行なった。す なわちラウリル，オレイル，ノニルフェニルエーテルの $n=4$ のものを試料とし, 各 $0.03 \mathrm{~g} / l$ 濃度溶液を作り, 容量で $1: 4,2: 3,3: 2,4: 1$ 飞和の扮の混ぜたるの の表面張力を測定した。矢の結果は図-5 亿示すとおり で混合物の表面張力はいずれの場合子各成分エーテルの 表面張力の中間の値を示している。ラウリルエーテルと オレイルエーテルの混合の場合前者による影響がかな り強く現われている。林ら ${ }^{17)}$ はオレイン酸ナトリウムと 他の脂肪酸ナトリウムの混合物の表面張力の低下が, 加 えた脂肪酸ナトリウムのアルキル基の長さと関係がある

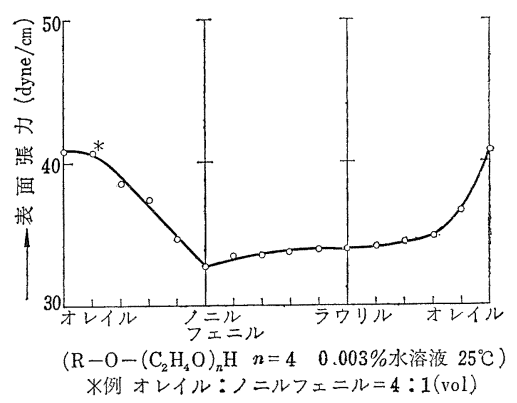

図-5 二成分混合物水溶液の表面張力-1 
ことを報告しているが，著者の場合な招数多くの実験を 行なわなければオキシェチレン鎖の長さが等しい場合同 族体蹯水基の影響とついての結論は得られない。オレイ ルーノニルフェニル,ノニルフェニルーラウリルの場合は ほとんぞ予想計算值に近い值が得られた。

$3 \cdot 2 \cdot 2$ 一成分が CMC を示す場合

つぎと表面張力ー濃度曲線が CMC をかなり明確に示 すエーテルと CMC を示さないもの，あるいはきわめ て水飞溶け飞くいものとを混合した場合飞ついて実験を 行なった。すなわち前者として $n=5$ のオレイルエーテ ルとノニルフェニルエーテル呿よび比較的 $\mathrm{CMC}$ が明 りょうでない $n=1$ のオレイルエーテルを選び後者とし て $n=1$ と 5 のセチルエーテルを選び，それらの組み合 わせ飞よる二成分混合物の表面張力を測定し，表面張力 一濃度曲線が CMC を明らか飞示すようとなる混合比を 求めた。それらの結果を図-6 から図-9 采で示す。

オキシエチレン鎖 1 個のオレイル招よびセチルエーテ ルの混合の場合を除き他の場合はいずれる界面活性なエ ーテルのみのときよりる表面張力は高く, $\mathrm{CMC}$ 亿相当

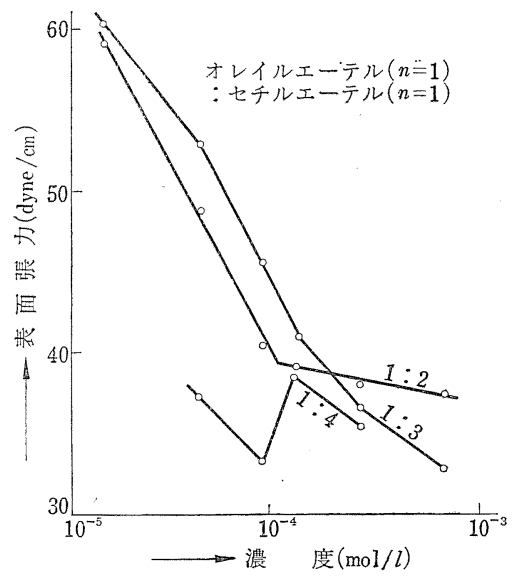

図-6 二成分混合物水溶液の表面張力 -2

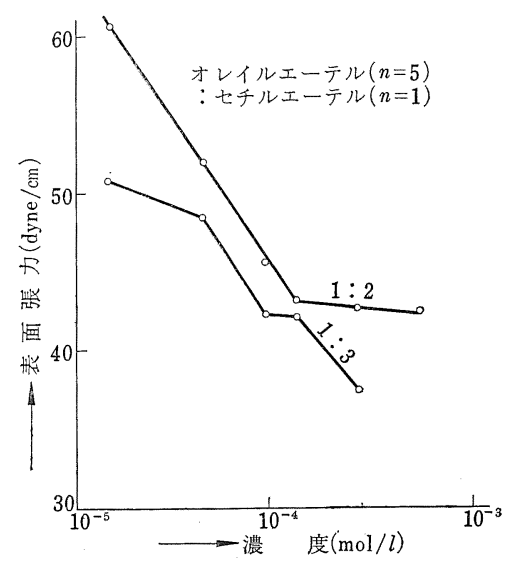

図-7 二成分混合物水溶液の表面張力 -3

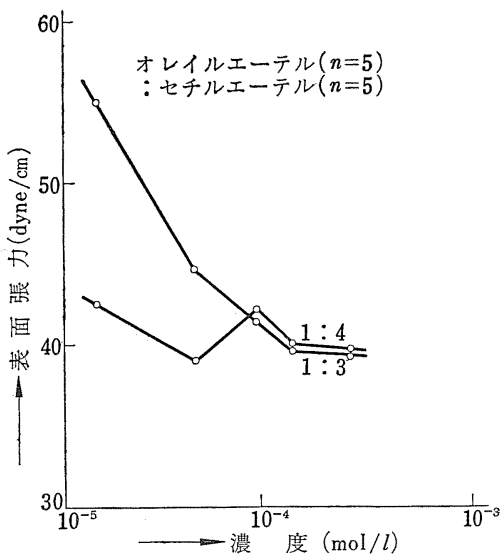

図-8 二成分混合物水溶液の表面張力 -4

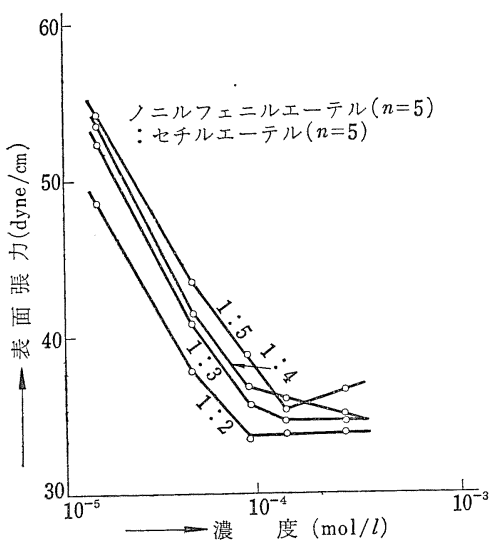

図-9 二成分混合物水溶液の表面張力 -5

する濃度は小となっており，その界面活性は混合のため そ減少している。またオキシエチレン鎖が1のオレイル エーテルに比べ表面張力の低下能の大きい $n=5$ のオレ イルエーテルでる $n=1$ のセチルエーテルと混合したと きは，先の曲線が明らかに CMC を示すのはオレイル エーテル：セチルエーテル＝1:2 のときが限度でそれ 以上セチルエーテルを加えると CMC は認められなくな る。この值は $n=1$ のオレイルエーテルと $n=1$ のセチ ルエーテルの混合の場合と同じで，この点関してはオ レイルエーテルの $n=1$ と 5 の間孰な差はないとと となる。一方 $n=5$ のセチルエーテルと $n=5$ のオレイ ルエーテルを混合した場合はオレイルエーテル：セチル エーテル $=1: 3$ でかなり明りょうと CMC を示した が，これは明らか、 $n=5$ のセチルエーテルが $3 \cdot 1.4$ 亿 も述べたようと，わずかながらも CMC を示す傾向が あるためと思われる。また $n=5$ のノニルフェニルエー テルと $n=5$ のセチルエーテルを混合したときは同じく 1:3で CMC が認められた。参考までにさらにセチル エーテルの量を少なくし，1:2の曲線を求めたとと ろ，曲線の折れは鋭くなりまた表面張力の低下も著し 
い。このことは中川らの結果とも一致する。したがって このような混合物の水溶液が $\mathrm{CMC}$ を明か、示すため には, 界面活性なエーテルの一定量に対し混合する界面 活性のないエーテルの量に限度があり, それは後者の性 質，てとに界面活性飞関する性質に上るとも考兄られる がな括今後の実験にまつものである。

終わりにのぞみ本実験に関し 終始御想切なる御指導をいただ いた 慶灾大学工学部教授阿部芳郎先生に深謝の意を表し, また 実験に援助いただいた 北里大学の石倉慶子氏に 感謝するしだい である。

本報文の一部は昭和 38 年 11 月 6 日油化学研究発表会於名 古屋, 講演。

\section{(昭和 39 年 2 月 11 日受理)$$
\text { 文献 }
$$

1) R. Baldacci, Ann. Chim. (Roma), 40, 358, 372 (1950)

2) A.N. Wrigley, F.D. Smith, A.J. Stirton, J. Am. Oil Chemists', Soc., 34, 39 (1957)

3) H. Lange, Kolloid-Z., 103, 9 (1959)
4) J. Stauff, J. Rasper, Kolloid-Z., 151, 148 (1957)

5) 中川, 栗山, 稲葉, 通, 日化, 77, 1563 (1956)

6) M. Cohen, Mémor. Serv. Chim. État (Paris), 37, 85 (1952)

7) L. Hsiao, H.N. Dunning, P.B. Lorentz, J. Phys. Chem., 60, 657 (1956)

8) P. Becher, J. Phys. Chem., 63, 1675 (1959)

9) 石井, 草野, 斉藤, 工化, 61, 180 (1958); 石井, 小川, 水谷, 工化, 64, 1794 (1961)

10) R.L. Mayhew, R.C. Hyatt, J. Am. Oil Chemists' Soc., 29, 357 (1952)

11）篠田, 山中, 木下, J. Phys. Chem., 63, 648 (1959)

12）阿部, 渡辺, 工化, 66, 1842 (1963)

13) W.D. Harkins, H.F. Jordan, J. Am. Chem. Soc., 52, 1751 (1930)

14）“実験化学講座”, Vol. 7, 14 (1951), 丸善

15) R.J. Vetter, J. Phys. \& Colloid Chem., 51, 262 (1947)

16) N. Sata, K. Chūjō, Bull. Chem. Soc., Japan, 26, 177 (1953)

17) 林, 淵沢, 難波, 油化学, 6, 208 (1957)

統 計（その2)

わが国油脂用途別需要量（会計年度）

(単位 $\mathrm{t}$ )

\begin{tabular}{|c|c|c|c|c|c|c|c|}
\hline & & & 食 & 用 & & & \\
\hline 年＼cjkstart次 & 工業用 & 加工用 & 単 体 & 計 & 内霹計 & 輸 出 & 総 計 \\
\hline 昭和 33 年 & 298,700 & 79,900 & 242,640 & 322,540 & 621,240 & 107,980 & 729,220 \\
\hline " 34 年 & 300,950 & 104,920 & 248,320 & 353,240 & 654,190 & 116,630 & 770,820 \\
\hline " 35 年 & 322,230 & 107,220 & 306,650 & 413,870 & 736,100 & 119,240 & 855,340 \\
\hline " 36 年 & 311,880 & 122,770 & 349,670 & 472,440 & 784,320 & 124,200 & 908,520 \\
\hline " 37 年 & 383,130 & 82,450 & 375,350 & 457,800 & 840,930 & 121,830 & 962,760 \\
\hline
\end{tabular}

（日本油脂工業会年報）

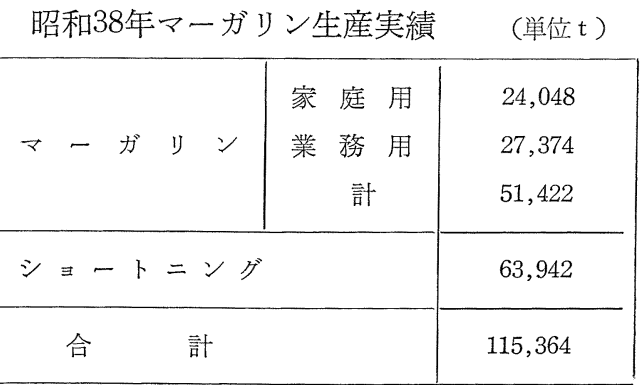

（日本油脂工業会年報）

(野中 正夫) 